\title{
The detection of plantaricin-encoding genes and their amino acid profiles in Lactobacillus plantarum AKK30 isolated from Indonesian native chicken
}

\author{
ELISABETH LOVIAN ULI BASA ${ }^{1}$, ABINAWANTO ${ }^{2, \bullet}$, A. SOPHIAN ${ }^{3}$, H. JULENDRA ${ }^{4}$, A. SOFYAN ${ }^{4}$ \\ ${ }^{1}$ Program of Biology, Graduate Program, Faculty of Mathematics and Natural Sciences, Universitas Indonesia. Jl. Lingkar UI, Depok 16424, West Java, \\ Indonesia \\ ${ }^{2}$ Department of Biology, Faculty of Mathematics and Natural Sciences, Universitas Indonesia. Jl. Lingkar UI, Depok 16424, West Java, Indonesia. \\ Tel.: +62-21-7270163, 78849009, Fax.: +62-21-78849010, ‘email: abinawanto.ms@ sci.ui.ac.id \\ ${ }^{3}$ National Agency of Drug and Food Control (BPOM Gorontalo). Jl. Toto Selatan, Bone Bolango 96128, Gorontalo, Indonesia \\ ${ }^{4}$ Reserach Unit for Natural Products Technology, Indonesian Institute of Sciences. Jl. Raya Wonosari Km 31.5, Playen, Gunung Kidul 55861, \\ Yogyakarta, Indonesia
}

Manuscript received: 19 November 2020. Revision accepted: 26 November 2020

\begin{abstract}
Elisabeth LUB, Abinawanto, Sophian A, Julendra H, Sofyan A. 2020. The detection of plantaricin-encoding genes and amino acid profile in Lactobacillus plantarum AKK30 isolated from Indonesian native chicken. Biodiversitas 21: 5792-5799. Plantaricinencoding genes of lactic acid bacteria (LAB) Lactobacillus plantarum AKK30 which was isolated from Indonesian native chicken has been characterized using DNA sequencing technology. In order to substitute antibiotics for chickens and enhance probiotics in their gut, characterization of the indigenous probiotics in the chicken should be conducted. A potential probiotic in native chicken gut is Lactobacillus plantarum AKK30. Genes that harbor the bacteriocin biosynthesis of the strain were reported for the first time. The bacterium has diverse plantaricin genes, i.e., $p \ln \mathrm{A}, p \ln \mathrm{EF}, p \ln \mathrm{J}, p \ln \mathrm{K}$ and $p \ln \mathrm{O}$. According to the dendrogram, the five plantaricin genes were closely related to $p \ln \mathrm{A}, p \ln \mathrm{E}, p \ln \mathrm{F}, p \ln \mathrm{J}, p \ln \mathrm{K}$ and $p \ln \mathrm{O}$ genes from L. plantarum WCFS1, L. plantarum C11, and L. plantarum V90. Intriguingly, besides various plantaricin-encoding genes, another important probiotic property in L. plantarum AKK30 is cholesterol-lowering activity. Amino acid profiling also indicated proteolysis activity and probiotic potential, for instance, GABA production. Thus, L. plantarum AKK30 may be added in chicken broiler's diet to provide probiotic benefits.
\end{abstract}

Keywords: Chromatography, DNA sequencing, Lactobacillus plantarum AKK30, native chicken, plantaricin

Abbreviations: Ala: Alanine, CLA: Conjugated linoleic acid, DNA: deoxyribonucleic acid, MRS: de Man, Rogosa and Sharpe, DMSO: dimethyl sulfoxide, GRAS: generally recognized as safe, Glu: Glutamic acid, Gly: Glycine, HPLC: high-performance liquid chromatography, LAB: lactic acid bacteria, PCR: polymerase chain reaction, Pro: Proline, UPLC: ultraperformance liquid chromatography

\section{INTRODUCTION}

Based on the Indonesian authorities' goals (Ministry of Agriculture Republic Indonesia), it is suggested that antibiotic treatment should be minimized. Therefore, probiotics could substitute any medicine in maintaining poultries' health. In addition, alternating antibiotics is useful to minimize residual consequences from the antibiotics administered in either poultries' or beef's meat. Furthermore, den Bogaard et al. (2001) and Kirbiš (2007) found that some microbes are resistant to antibiotic residues, which are either from meat or food industries. Consequently, it is dangerous when meat containing antibiotic residue is consumed by humans as the antibiotic residue may cause toxicity.

Lactobacillus is known for its probiotic potential. Lactobacillus plantarum, lactic acid bacteria (LAB), is a member of the genus Lactobacillus bacterium, a Grampositive facultative anaerobic (Menconi et al. 2014; Arasu et al. 2016) and a versatile species (de Vries et al. 2006). These special characteristics make the species a safe probiotic, known as GRAS or generally recognized as safe
(Deegan et al. 2006; Settanni and Corsetti 2007). In addition, Lactobacillus is also known for its conjugated linoleic acid (CLA) production ability (Wen Jiang et al. 2014; Linares et al. 2017). Moreover, probiotic potential from Lactobacillus is beneficial for animals and humans. One reason is the cholesterol-lowering activity of the Lactobacillus (Linares et al. 2017). Hence, ability of the Lactobacillus to lower cholesterol is important to be investigated besides its probiotic production.

This paper focuses on the probiotics used for poultry. Huang et al. (2004) and Kabir (2009) found that probiotics are beneficial for the chickens as they found that provision of prebiotic caused significantly positive effect on the poultries' immune systems and meat quality. In addition, Lactobacillus spp. is known to have an effective anticancer ability in human intestines for good human health (Kieun Lee and Yeonhee Lee 2009; Masood et al. 2011).

An indigenous $\mathrm{LAB}$ strain of $L$. plantarum in Indonesia, namely $L$. plantarum AKK30 (Figure 1) was first reported by Julendra et al. (2017). The bacteria were isolated from the colons of native Indonesian chicken. Intriguingly, L. Plantarum AKK30 has the highest in vitro 
test by using microplate reader (ppb) percentage cholesterol-lowering activity for decreasing cholesterol among the bacteria isolated from Indonesian chicken intestinal tracts as conducted by Julendra et al. (2017) with formula as: Cholesterol-lowering Percentage $=[$ (cholesterollowering $(\mu \mathrm{g} / \mathrm{mL})]^{*} 100 \%$ (Table 1). Therefore, it is interesting to carry out research about $L$. plantarum AKK30, since it is isolated from Indonesian native chicken and has beneficial properties.

Bacteria from the genera Lactobacillus, Lactococcus, Pediococcus, and Streptococcus are well known for their bacteriocin, a complex protein that can be an effective antibacterial protein (Deegan et al. 2006; Todorov 2009). Bacteriocin isolated from L. Plantarum is known as plantaricin. For instance, plantaricin SLG1 from $L$. plantarum SLG1 was reported for its bacteriocin biosynthesis (Jinjin Pei et al. 2018). This plantaricin was found to have activity against Gram-negative bacteria and fungi. Particularly, it inhibits the growth of Listeria monocytogenes, which is a known culprit in food-borne disease (Farber and Peterkin 1991). Therefore, research about plantaricin genes in L. plantarum is interesting to be conducted.

Plantaricin characterization has been usually conducted by using chromatography and sequencing (Jiménez-Díaz et al. 1995; Holo et al. 2001; Maldonado et al. 2003; Sabo et al. 2014; Jinjin Pei et al. 2018). One of the advantages of plantaricin gene characterization is to provide useful information about a particular LAB strain. However, study about L. plantarum AKK 30, especially about plantaricin is still limited. Here,this paper described the five $p l n$ genes, namely $p \ln \mathrm{A}, p \ln \mathrm{EF}, p \ln \mathrm{J}, p \ln \mathrm{K}$, and $p \ln \mathrm{O}$ in L. plantarum AKK30 characterized by using DNA sequencing technology. This information hopefully could be utilized to suggest alternative antibiotics for poultries.

\section{MATERIALS AND METHODS}

\section{Lactobacillus plantarum AKK30 and DNA extraction}

Lactobacillus plantarum strain AKK30 isolates were obtained from Research Center for Natural Product Technology (BPTBA), Indonesian Institute of Sciences (LIPI), Gunungkidul, Yogyakarta, Indonesia. The bacteria culture was incubated in de Man, Rogosa, and Sharpe (MRS) broth at $37^{\circ} \mathrm{C}$ and then kept at $4{ }^{\circ} \mathrm{C}$. The genomic
DNA of bacteria was extracted by using gDNA wizard extraction kit (Promega). Micro-volume spectrophotometer (BioDrop) was used to calculate the gDNA concentration.

\section{Plantaricin genes amplification and DNA sequencing}

Plantaricin genes were amplified by using polymerase chain reaction (PCR) with primers are included (Table 2). Two polymerase enzyme kits were used, i.e., $3 \mathrm{uM} \mathrm{MgCl}_{2}$ Pol MasterMix and TaqPol kit (ProMega) for amplification due to optimized concentration of $\mathrm{MgCl}_{2}$. In addition, $5 \%$ dimethyl sulfoxide (DMSO) was also used for each amplification reaction in the total mixture volume $25 \mu \mathrm{L}$. Then the mixture was added Followed by $0.75 \mu \mathrm{M}$ of $\mathrm{MgCl}_{2}$, specifically while using TaqPol kit for $p \ln \mathrm{A}$ and $p \ln \mathrm{EF}$ genes amplification. The final concentration from each primer was $0.35 \mu \mathrm{M}$. The PCR conditions are described in Table 3.

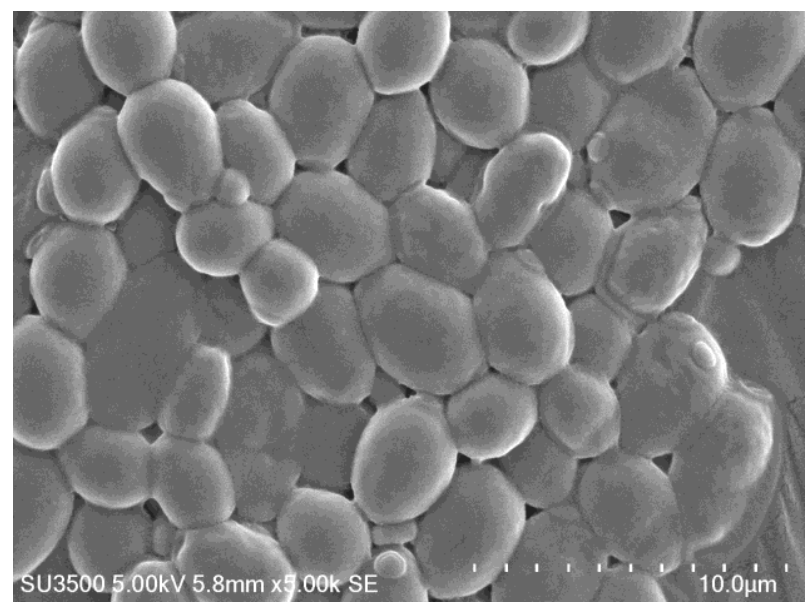

Figure 1. Image of Lactobacillus plantarum (each rod-shaped figure) AKK30 from BPTBA-LIPI picture was taken by using scanning electron microscope (Hitachi SU3 500)

Table 1. In vitro test of cholesterol-lowering activity results done by Julendra et al. (2017)

\begin{tabular}{ccc}
\hline No. & LAB isolates & \% \\
\hline 1 & AKK30 & $17.43 \%$ \\
2 & AKU-4 & $15.24 \%$ \\
3 & AKS-16 & $15.02 \%$ \\
4 & AKS-19 & $8.41 \%$ \\
\hline
\end{tabular}

Table 2. Primers sequence of plantaricin genes amplification

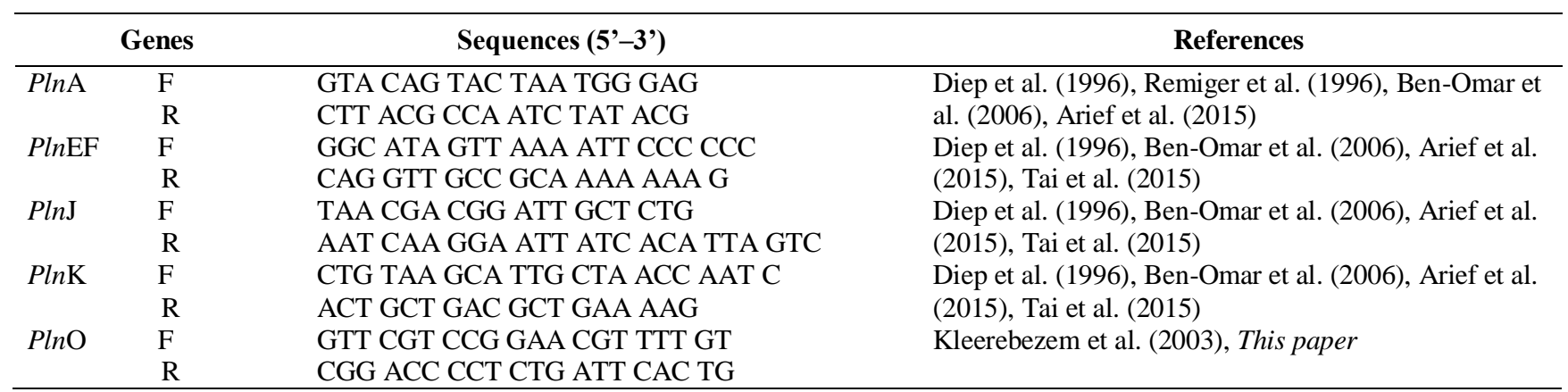


Table 3. PCR conditions for plantaricin genes amplification

\begin{tabular}{lccc}
\hline \multicolumn{1}{c}{ Stage } & $\begin{array}{c}\text { Cycle } \\
\text { (times) }\end{array}$ & $\begin{array}{c}\text { Temp } \\
\left({ }^{\circ} \mathbf{C}\right)\end{array}$ & $\begin{array}{c}\text { Duration } \\
(\text { min:sec) }\end{array}$ \\
\hline Predenaturation & 1 & 95 & $5: 00$ \\
Denaturation & & 95 & $1: 00$ \\
Annealing & 35 & 60 & $1: 00$ \\
Extention & & 72 & $1: 00$ \\
Postextention & 1 & 72 & $5: 00$ \\
Hold & & 8 & $\infty$ \\
\hline
\end{tabular}

\section{Liquid-phase based chromatography}

The culture was divided into two tubes with two different concentrations of inulin (I), i.e., $0 \%$ and $0.5 \%$. The inulin with $0.5 \%$ concentration was used based on Julendra et al. (2019) who found that addition of $0.5 \%$ inulin helped the fermentation process of the bacteria in $L$. plantarum AKK30 medium. Amino acid composition was determined by using ultra-performance liquid chromatography (UPLC) and high-performance liquid chromatography (HPLC) which completed with column chromatography of AccQ. Tag Ultra C18 $1.7 \mu \mathrm{m}(2.1 \times 100$ $\mathrm{mm})$ and Merck Lichospher $25 \mathrm{~cm} \times 4.0 \mathrm{~mm}, 5 \mu \mathrm{m}$, respectively.

\section{Data analysis}

Capillary electrophoresis sequencing (CES) from MacroGen (South Korea) DNA sequencing service was used for sequencing the PCR amplicons. The DNA sequencing results were compared with the existing data in the NCBI by using a basic local alignment search tool (BLAST) alignment. Dendrogram for phylogenetic analysis was constructed using NJplot and ClustalX. Measurement which was used for grouping was 1000 bootstrap replicates (Perrière and Gouy 1996).

\section{RESULTS AND DISCUSSION}

\section{Lactobacillus plantarum AKK30 DNA concentration}

Culture of L. plantarum AKK30 was obtained from Research Division for Natural Product Technology (BPTBA), Indonesian Institute of Sciences (LIPI), Gunungkidul, Yogyakarta, Indonesia. The extracted DNA concentration was quantified by using a spectrophotometer in micro-volume. Result of the extracted DNA concentration was $116.6 \mathrm{ng} \mu \mathrm{L}^{-1}$. Proportion of the results of UV absorbance for A260/A230 and A260/A280 were 2.216 and 2.024 , respectively.

\section{Lactobacillus plantarum AKK30 DNA sequencing}

The first characterization of diversity of plantaricin genes in L. plantarum AKK30 was successfully described. The genes were $p \ln \mathrm{A}, p \ln \mathrm{EF}, p \ln \mathrm{J}, p \ln \mathrm{K}$, and $p \ln \mathrm{O}$. The PCR products were separated using electrophoresis (Figure 2) and the nucleotide sequence of the amplified PCR products was sequenced by using a CES and presented in an electropherogram (Figures 3).
Based on the DNA sequencing results, a BLASTn alignment analysis was done against NCBI data. However, the was no significant alignment of the NCBI database with our DNA sequence data. Then, a phylogenetic tree was constructed to look for the similarity between $p l n$ genes $(p \ln \mathrm{A}, p \ln \mathrm{EF}, p \ln \mathrm{J}, p \ln \mathrm{K}$, and $p \ln \mathrm{O})$. The result of cluster analysis showed that bootstrap of 1000 indicates the highest similarity $(100 \%)$ between the genes at the same sub-cluster. The scale bar indicates 0.05 nucleotide substitution per nucleotide position of plantaricin gene (Figure 4).

In this study, pln genes in the database are L. plantarum WCFS1 (accession number: NC_004567.2), L. plantarum pln gene locus, strain C11 (accession number: X94434.2), and L. plantarum strain V90 pln gene locus, partial sequence (accession number: FJ809773.1). These strains were selected for phylogenetic analysis because $L$. plantarum WCFS1 is the first strain to be completely sequenced (Kleerebezem et al. 2003). Additionally, plantaricin genes in L. plantarum $\mathrm{C} 11$ have been characterized and reported by Diep et al. (1996). Moreover, L. plantarum V90 is the novel pln locus which is identical to those two aforementioned strains and reviewed by Diep et al. (2009).

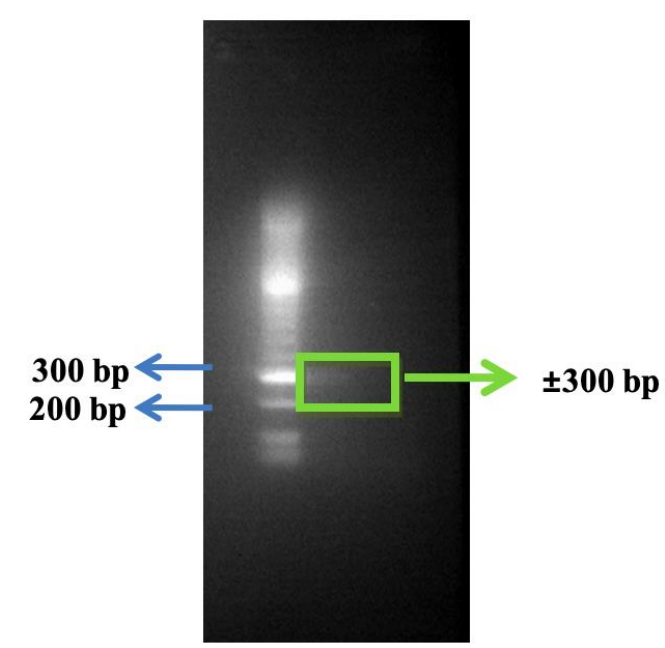

Figure 2. The electrophoresis of $\mathrm{PCR}$ product of $p \ln \mathrm{O}$ gene in Lactobacillus plantarum AKK30. The pointed green box and arrow indicated the expected band of 300bp
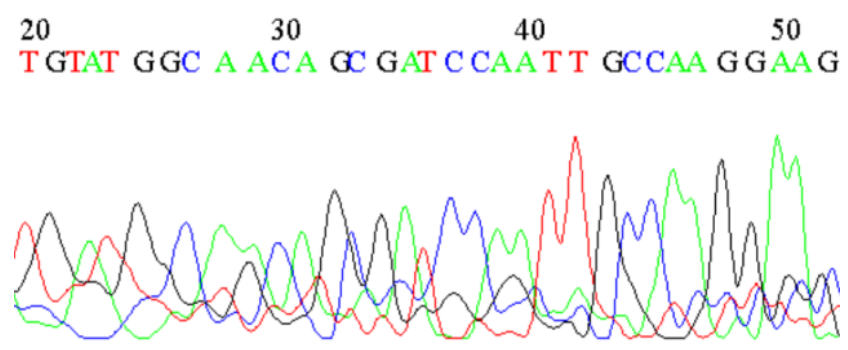

Figure 3. Electropherogram of $p l n \mathrm{O}$ gene in Lactobacillus plantarum AKK30 


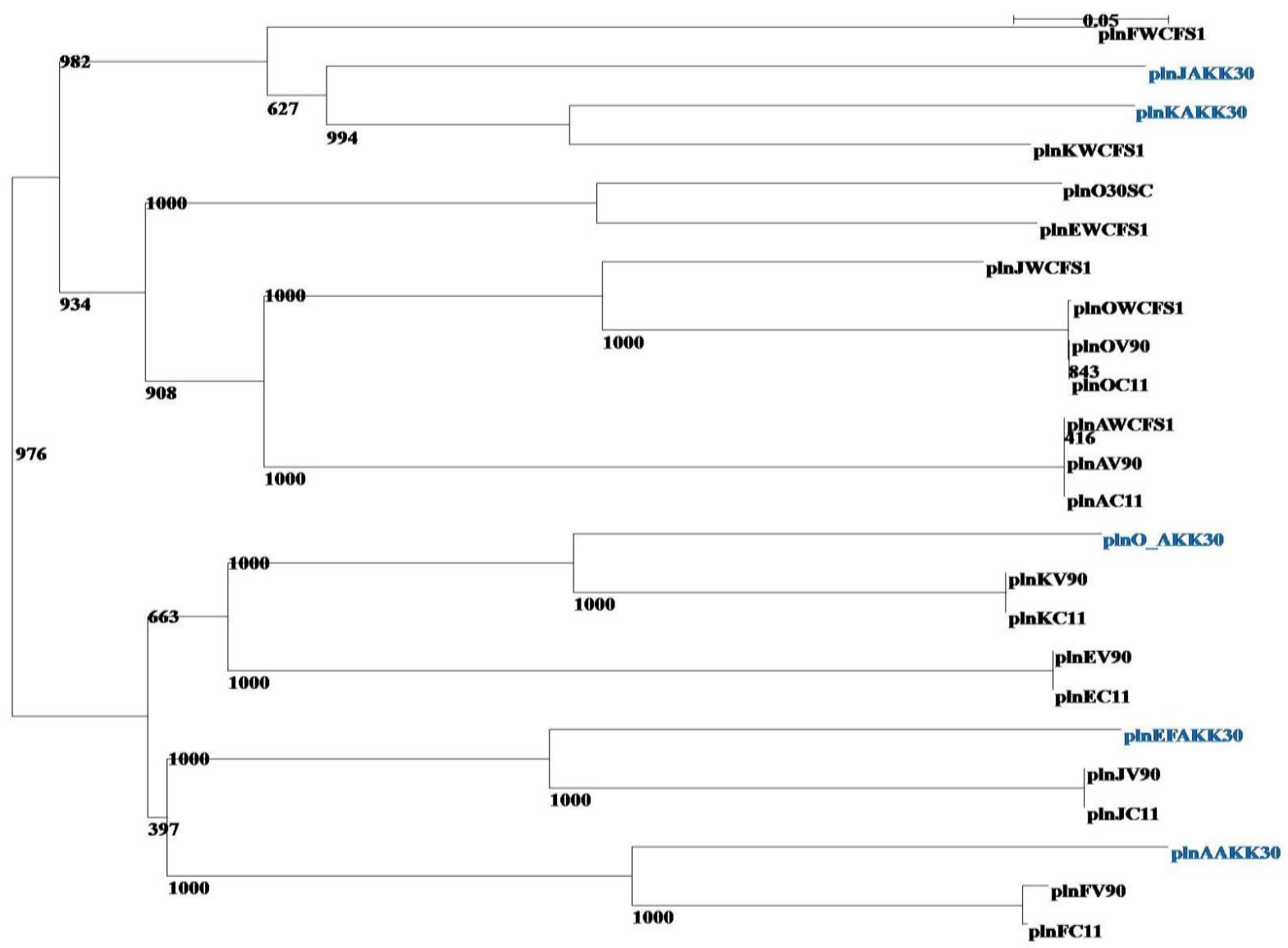

Figure 4. The dendrogram of Lactobacillus plantarum AKK30 (blue) plantaricin genes analysis
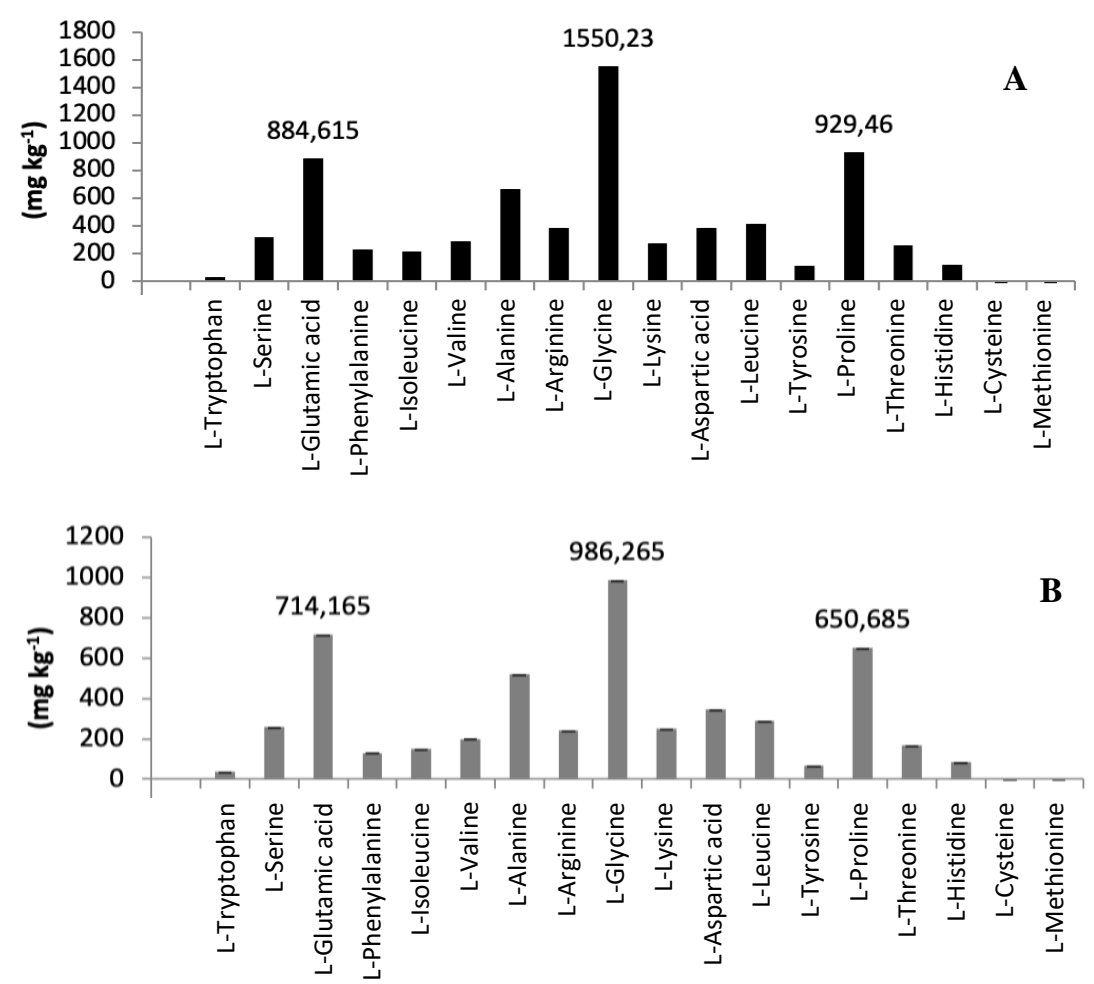

Figure 5. A. Amino acid profile of Lactobacillus plantarum AKK30 without Inulin (Control group, 0\% inulin); B. Amino acid profile of L. plantarum AKK30 with $0.5 \%$ Inulin 
Table 4. Three amino acids found in high amount $\left(\mathrm{mg} \mathrm{kg}^{-1}\right)$ in the culture with $(0 \%)$ and $(0.5 \%)$ inulin

\begin{tabular}{lcc}
\hline \multirow{2}{*}{ Amino acid } & \multicolumn{2}{c}{ Oligosaccharides (inulin) } \\
\cline { 2 - 3 } & $\mathbf{0 \%}$ & $\mathbf{0 . 5 \%}$ \\
\hline Glycine & 1550.23 & 986.265 \\
Proline & 929.46 & 650.685 \\
Glutamic acid & 884.615 & 714.165 \\
\hline
\end{tabular}

Amino acid sequence in L. plantarum AKK30 has been identified and Glycine (Gly) is the most prevalent amino acid (Figure 5a, 5b and Table 4). However, amino acid compound in L. plantarum AKK30 with additional $0.5 \%$ was $36 \%$ inulin was less than glycine in control group or with $0 \%$ inulin. Inulin was added because it is indispensable for $L$. plantarum in its growth and viability (Gänzle and Follador 2012; Valero-Cases and Frutos 2017). Our result showed that Gly was the amino acid most abundantly found in our sample, i.e., $1550.23 \mathrm{mg} \mathrm{kg}^{-1}$ and $986.265 \mathrm{mg} \mathrm{kg}^{-1}$ in $0 \%$ and $0.5 \%$ inulin concentration, respectively. Moreover, based on the results, Alanine (Ala) concentration level was higher than that of other types of amino acids, besides Proline (Pro) and Glutamic acid (Glu), $664.175 \mathrm{mg} \mathrm{kg}^{-1}$ and $519.87 \mathrm{mg} \mathrm{kg}^{-1}$ in $0 \%$ and $0.5 \%$ inulin concentration, respectively. Thus, L. plantarum AKK30 may produce plantaricin based on the result, as indicated by the Gly and Ala levels.

\section{Discussion}

Results of BLASTn alignment showed no significant similarities between our nucleotide sequences with the database, consequently, the phylogenetic tree analysis was done in order to characterize the pln genes of L. plantarum AKK30. The dendrogram showed that AKK30 pln genes were divided into two clusters. In this paper, $p \ln$ genes in the sample, i.e., L. plantarum strain AKK30, were explained first. In general, it is interesting that according to the phylogenetic tree, pln genes from AKK30 are closely related to the $p l n$ genes in the database with bootstrap of around 1000 indicating close similarity between genes in the clade (Holmes 2003).

Firstly, $p \ln K$ gene from L. plantarum AKK30 was found to be closely related in one cluster with $p \ln \mathrm{K}$ gene from $L$. plantarum strain WCFS1, the first strain of $L$. plantarum which has been completely sequenced (Kleerebezem et al. 2003). In addition, the cluster has bootstrap value of 994 with $p l n \mathrm{~J}$ gene from L. plantarum AKK30. The results showed that $p \ln \mathrm{J}$ and $p \ln \mathrm{K}$ genes from L. plantarum AKK30 are closely related. Moreover, it is a significant finding that these genes were closely related and hypothesized as a group in the $p \ln \mathrm{JK}$ bacteriocin. Bacteriocin, namely $p \ln \mathrm{JK}$ is a member of class IIb twopeptide bacteriocins whose activity is dependent on the action of two different peptides (Diep et al. 2009). Also, analysis of immunity function of $p \ln \mathrm{K}$ in L. plantarum strain WCFS1 as supported by the phylogenetic analysis result, showed that they had closely related one another.
Secondly, other $p \ln$ genes, namely $p \ln \mathrm{A}, p \ln \mathrm{EF}$, and $p \ln \mathrm{O}$ from $L$. plantarum strain AKK30 according to another cluster showed an interesting result. The $p l n$ genes tended to be in a group with $p l n$ genes from $L$. plantarum strain C11 and L. plantarum strain V90. This was particularly true for $p \ln \mathrm{K}, p \ln \mathrm{J}$, and $p \ln \mathrm{F}$ genes. On the other hand, $p \ln \mathrm{O}$ and $p \ln \mathrm{A}$ genes from $L$. plantarum strain WCFS1, L. plantarum strain C11, and L. plantarum strain V90 tended to be in one group and were analyzed as in one node with plnJ gene from L. plantarum strain WCFS1.

The analysis results showed that plnEFL. plantarum AKK30 has quite similar characteristics as plnJ from $L$. plantarum strain $\mathrm{C} 11$ and V90. In addition, plnEF and plnJK are bacteriocins that consist of two peptides (Diep et al. 1996). Moreover, it is hypothesized that the $p \ln \mathrm{A}$ gene in the sample might be as strong as $p \ln \mathrm{F}$ of $L$. plantarum $\mathrm{C} 11$ and V90 in immunity level. This was supported by the results that $p \ln \mathrm{A} L$. plantarum $\mathrm{AKK} 30$ as depicted by the phylogenetic tree, $p \ln \mathrm{A}$ was closely related to $p \ln$ Ffrom $L$. plantarum strain $\mathrm{C} 11$ and V90. Furthermore, it is intriguing that plnABCD operon in L. plantarum AKK30 is important in coding for a quorum-sensing network for expression of all the pln genes (Diep et al. 2009). The statement that plantaricin $\mathrm{A}$, which was matured from $p \ln \mathrm{A}$ gene, is impedance as induction factor in bacteriocin biosynthesis is supported by Diep et al. (1996) study findings.

$P l n$ genes reported in this paper were isolated from LAB found in indigenous chicken and has cholesterollowering activity. The genes reported here are also responsible for plantaricin biosynthesis. The phylogenetic tree showed that L. plantarum AKK30 has important plantaricin genes and operons. In addition, bacteriocin and antibiotics are quite similar to bactericidal compounds, but bacteriocin is synthesized in ribosome, whereas antibiotics are secondary metabolites (Deegan et al. 2006). Bacteriocins may be originated or encoded either from the chromosome or plasmid (Todorov 2009; Silva Sabo et al. 2014). Most bactericidal bacteriocins usually display modes of action towards closely related species (Deegan et al. 2006; Todorov 2009). Moreover, genes that play important roles in immunity and production are usually found to cluster in operons, i.e., plnABCD, plnEFI, plnJKLR, $p \ln$ GHSTUVW, and $p \ln$ MNOP (Diep et al. 2009). Therefore, plantaricin biosynthesis is also an important preference in producing probiotic.

Operons that have been reported are $p \ln \mathrm{ABCD}$ operon for regulatory operon which is important for quorum sensing. In addition, plantaricin A from $p \ln \mathrm{A}$ also has immunity properties, even though peptides expressed by $p \ln \mathrm{EF}$ are still stronger in immunity level. plnEFI and plnJKLR operons are reported to involve in immunity. The transport operon consists of plnGHSTUVW, which helps coding for an ABC-transporter and an accessory protein in secretion of peptides employing a leader of double-glycine. Double-glycine is important to mark a plantaricin biosynthesis in a particular L. plantarum (Diep et al. 1996; Anderssen et al. 1998; Diep et al. 2009). Operon plnOP is reported to be responsible for coding proteins, namely plnO and plnP with significant homology to family 2-glycosyl 
transferases and type II CAAX amino proteases, respectively (Diep et al. 2009).

For profiling amino acid in L. plantarum AKK30, it is interesting that inulin addition did not promote any synthesis, whereas it decreased the amino acid biosynthesis. The L. plantarum AKK30 has pln genes based on the glycine content described in this paper. However, additional inulin in the culture media did not affect the bacteria. Liquid chromatography assay, in particular UPLC, is recommended for amino acid analysis for this study.

Characterization of amino acid compounds in $L$. plantarum AKK30 was done by using UPLC and HPLC. Liquid chromatography, like UPLC, was used due to its sensitivity (Delavenne et al. 2011; Meussen et al. 2014; Galba et al. 2016). In this paper, the focus of discussion is on three amino acids with the highest concentration levels (exceeds $500 \mathrm{mg} \mathrm{kg}^{-1}$ ), i.e., Gly, Pro, and Glu. The amino acid which may indicate bacteriocin biosynthesis was Glycine, due to the double-Glycine found in plantaricin (Diep et al. 1996; Anderssen et al. 1998; Diep et al. 2009; Todorov 2009). In addition, high concentration levels of either Gly or Ala may indicate that there is biosynthesis of plantaricin (Jiménez-Díaz et al. 1995; Barbosa et al. 2016).

Lactobacillus plantarum was known for proteolytic ability by secreting proline iminopeptidase (PIP) (Chanalia et al. 2018). Our result showed that L. plantarum AKK30 may produce PIP indicated by Pro concentration level, $929.46 \mathrm{mg} \mathrm{kg}^{-1}$ and $650.685 \mathrm{mg} \mathrm{kg}^{-1}$ in $0 \%$ and $0.5 \%$ inulin concentrations, respectively. In addition, it was proven that LAB harbors the gene responsible for Glu expression (Tanous et al. 2005; Zareian et al. 2013). This is indispensable as a precursor in $\gamma$-aminobutyric acid (GABA) production ( $\mathrm{Li}$ and Cao 2010; Rongzhen Zhang et al. 2014; Yunes et al. 2016). Chromatography results indicated that L. plantarum AKK30 may produce GABA as Glu concentration level exceeded $500 \mathrm{mg} \mathrm{kg}^{-1}$, i.e., 884.615 $\mathrm{mg} \mathrm{kg} \mathrm{kg}^{-1}$ and $714.165 \mathrm{mg} \mathrm{kg}^{-1}$ in $0 \%$ and $0.5 \%$ inulin concentrations, respectively.

Interestingly, the results showed that oligosaccharide did not oblige L. plantarum AKK30 in increasing amino acid level, even though, oligosaccharide is important in the L. plantarum AKK30 fermentation process (Julendra et al. 2019). We speculated that inulin has a negative-inducing lactose effect and the oligosaccharide was utilized for growth. This speculation was supported by study about operon in L. plantarum by Buntin et al. (2016) which showed that inulin is utilized as carbon source and indispensable for growth and viability of L. plantarum.

The present study results revealed five important plantaricin gene sequences in L. plantarum AKK30, a strain isolated from indigenous chicken. The amino acid profiling conducted by Cui Jin Toe et al. (2019) supports the chromatographic results of $L$. plantarum AKK30 and the suspected proteolytic activity of this strain. The data show proline levels above $500 \mathrm{mg} \mathrm{kg}^{-1}$. Lactic acid bacteria are known to have a gene for the production of glutamic acid (Glu) (Tanous et al. 2005; Zareian et al. 2013) which is important as a precursor for $\gamma$-aminobutyric acid (GABA) production (Li and Cao 2010; Rongzhen Zhang et al. 2014; Yunes et al. 2016). Based on the chromatographic data of L. plantarum AKK30, Glu is an amino acid found in high amounts $\left(884.615 \mathrm{mg} \mathrm{kg}^{-1}\right.$ and $714.165 \mathrm{mg} \mathrm{kg}^{-1}$ for both inulin concentrations) in the sample. The data is supported by amino acid research in LAB by Cui Jin Toe et al. (2019), which shows a high Glu production of the eight samples (331.74 $\left.\mathrm{mg} \mathrm{L}^{-1}\right)$. Alleged GABA production, based on Glu amino acid data from L. plantarum AKK30, is supported by several research results related to the production of Glu amino acids and the ability of LAB to produce acids amino nonpeptides (Tanous et al. 2005; Li and Cao 2010; Zareian et al. 2013; Rongzhen Zhang et al. 2014; Yunes et al. 2016). Interestingly, the Gly is not among the top three amino acids of the strain $\left(94.90 \mathrm{mg} \mathrm{L}^{-}\right.$ $\left.{ }^{1}\right)$. However, these strains are included in the five sample strains yielding the amino acid Gly with a value approaching $100 \mathrm{mg} \mathrm{L}^{-1}$.Pro amino acids are mostly found in P. pentosaceus strain UL-6, amounting to $169.53 \mathrm{mg} \mathrm{L}^{-1}$. One of the LAB samples tested was from the genus Lactobacillus is L. plantarum UL-4. Based on the strain data, the three amino acids with the highest levels were Lysine (Lys), Glu, and Leucine (Leu). The strain is also not included in the strains discussed were related to the significance of the amino acid values of the eight LAB test strains. In conclusion, here we reported for the first time about five plantaricin genes in Lactobacillus plantarum $\mathrm{AKK} 30$, i.e., $p \ln \mathrm{A}, p \ln \mathrm{EF}, p \ln \mathrm{J}, p \ln \mathrm{K}$, and $p \ln \mathrm{O}$. The strain has diverse plantaricin genes, and it is interesting that $L$. plantarum strain from indigenous chicken in Indonesia is distinct. L. plantarum AKK30 is also a potential probiotic based on the amino acid profiling results.

\section{ACKNOWLEDGEMENTS}

This study was supported financially through Direktorat Riset \& Pengabdian Masyarakat, Universitas Indonesia, Depok, Indonesia through "Publikasi Internasional Terindeks untuk Tugas Akhir Jurnal Q4 (HIBAH PITTA A)" Research Grant (Contract number: NKB-0429/UN2.R3.1/HKP.05.00/ 2019. The authors would like to thank BPTBA-LIPI, Gunung Kidul, Indonesia for the L. plantarum AKK30 isolates. Also, the authors would like to thank Putra M. Tampubolon and BPOM Gorontalo for their help in DNA sequencing data analysis and for $p \ln \mathrm{O}$ genes primer designing, respectively. Lastly, the authors would like to thank Jocelyn M. Huang for providing substantial improvements to the paper. There was no conflict of interest while conducting the research.

\section{REFERENCES}

Anderssen EL, Diep DB, Nes IF, Eijsink VGH, Nissen-Meyer J. 1998. Antagonistic activity of Lactobacillus plantarum C11: Two new twopeptide bacteriocins, plantaricins EF and JK, and the induction factor plantaricin A. Appl Environ Microbiol 64 (6): 2269-2272. DOI: 10.1128/AEM.64.6.2269-2272.1998.

Arasu MV, Al-Dhabi NA, Ilavenil S, Ki Choon Choi, Srigopalram S. 2016. In vitro importance of probiotic Lactobacillus plantarum related to medical field. Saudi J Biol Sci 23 (1): S6-S10. DOI: 10.1016/j.sjbs.2015.09.022. 
Arief II, Budiman C, Jenie BSL, Andreas E, Yuneni A. 2015. Plantaricin IIA-1 A5 from Lactobacillus plantarum IIA-1 A5 displays bactericidal activity against Staphylococcus aureus. Benef Microbes 6 (4): 603 613. DOI: 10.3920/BM2014.0064.

Ben-Omar N, Abriouel H, Lucas R, Martínez-Cañamero M, Guyot J-Pi, Gálvez A. 2006. Isolation of bacteriocinogenic Lactobacillus plantarum strains from ben saalga, a traditional fermented gruel from Burkina Faso. Int J Food Microbiol 112 (1): 44-50. DOI: 10.1016/j.ijfoodmicro.2006.06.014.

Buntin N, Hongpattarakere T, Ritari J, Douillard FP, Paulin L, Boeren S, Shetty SA, de Vos WM. 2016. An inducible operon is involved in inulin utilization in Lactobacillus plantarum strains, as revealed by comparative proteogenomics and metabolic profiling. Appl Environ Microbiol 83: 1-13.

Chanalia P, Gandhi D, Attri P, Dhanda S. Extraction, purification and characterization of low molecular weight proline iminopeptidase from probiotic L. plantarum for meat tenderization. Int J Biol Macromol 109: 651-663. DOI: 10.1016/j.ijbiomac.2017.12.092.

Sabo S, Vitolo M, González JMD, de Souza Oliveira RP. 2014. Overview of Lactobacillus plantarum as a promising bacteriocin produce among lactic acid bacteria. Food Res Int 64: 527-536. DOI: 10.1016/j.foodres.2014.07.041.

de Vries MC, Vaughan EE, Kleerebezem M, de Vos WM. 2006 Lactobacillus plantarum - survival, functional and potential probiotic properties in the human intestinal tract. Int Dairy J 16: 1018-1028. DOI: 10.1016/j.idairyj.2005.09.003.

Deegan LH, Cotter PD, Hill C, Ross P. 2006. Bacteriocins: Biological tools for bio-preservation and shelf life extension. Int Dairy J 16: 1058-1071. DOI: 10.1016/j.idairyj.2005.10.026

Delavenne X, Juthier L, Pons B, Mariat C, Basset T. 2011. UPLC MS/MS method for quantification of mycophenolic acid and metabolites in human plasma: Application to pharmacokinetic study. Clinica Chimica Acta 412: 59-65. DOI: 10.1016/j.cca.2010.09.041.

den Bogaard AE, London N, Driessen C, Stobberingh EE. 2001 Antibiotic resistance of faecal Escherichia coli in poultry, poultry farmers and poultry slaughterers. J Antimicrob Chemother 47 (6): 763-771. DOI: 10.1093/jac/47.6.763.

Diep DB, LS Håvarstein, IF Nes. 1996. Characterization of the locus responsible for the bacteriocin production in Lactobacillus plantarum C11. J Bacteriol 178 (15): 4472-4483. DOI: 10.1128/jb.178.15.44724483.1996.

Diep DB, Straume D, Kjos M, Torres C, Nes IF. 2009. An overview of the mosaic bacteriocin pln loci from Lactobacillus plantarum. Peptides 30 (8): 1562-1574. DOI: 10.1016/j.peptides.2009.05.014

Farber JM, Peterkin PI. 1991. Listeria monocytogenes, a food-borne pathogen. Microbiol Rev 55 (3): 476-511.

Gänzle MG, Follador R. 2012. Metabolism of oligosaccharides and starch in lactobacilli: A review. Front Microbiol 3: 340. DOI: 10.3389/fmicb.2012.00340.

Holmes S. 2003. Bootstrapping phylogenetic trees: theory and methods. Statistic Sci 18 (2): 241-255.

Holo H, Jeknic Z, Daeschel M, Stevanovic S, Nes IF. 2001. Plantaricin W from Lactobacillus plantarum belongs to a new family of two-peptide lantibiotics. Microbiology 147 (3): 643-651. DOI: 10.1099/00221287147-3-643

Huang MK, Choi YJ, Houde R, Lee J-W, Lee B, Zhao X. 2004. Effects of Lactobacilli and an acidophilic fungus on the production performance and immune responses in broiler chickens. Poult Sci 83 (5): 788-795. DOI: $10.1093 / \mathrm{ps} / 83.5 .788$

Tai HF, Foo HL, Rahim RA, Loh TC, Abdullah MP, Yoshinobu K. 2015. Molecular characterization of new organization of $p \ln E F$ and $p l w$ loci of bacteriocin genes harbor concomitantly in Lactobacillus plantarum I-UL4. Microb Cell Fact 14: 89. DOI: 10.1186/s12934-015-0280-y.

Jiang W, Nie S, Qu Z, Bi C, Shan A. 2014. The effects of conjugated linoleic acid on growth performance, carcass traits, meat quality, antioxidant capacity, and fatty acid composition of broilers fed corn dried distillers grains with solubles. Poult Sci 93 (5): 1202-1210. DOI: $10.3382 /$ ps.2013-03683.

Jiménez-Díaz R, Ruiz-Barba JL, Cathcart DP, Holo H, Nes IF, Sletten KH, Warner PJ. 1995. Purification and partial amino acid sequence of plantaricin S, a bacteriocin produced by Lactobacillus plantarum LPCO10, the activity of which depends on the complementary action of two peptides. Appl Environ Microbiol 61 (12): 4459-4463. DOI: 10.1128/AEM.61.12.4459-4463.1995.

Jinjin P, Li X, Han H, Tao Y. 2018. Purification and characterization of plantaricin SLG1, a novel bacteriocin produced by $\mathrm{Lb}$. plantarum isolated from yak cheese. Food Control 84: 111-117. DOI: 10.1016/j.foodcont.2017.07.034.

Julendra H, Sofyan A, Abinawanto, Yasman. 2019. Improving antibacterial activity and viability of Lactobacillus plantarum AKK30 as feed additive by addition of different oligosaccharides. IOP Conf Ser Earth Environ Sci 251: 1-7. DOI: 10.1088/1755$1315 / 251 / 1 / 012051$

Julendra H, Suryani AE, Istiqomah L, Damayanti E, Anwar M, Fitriani N. 2017. Isolation of lactic acid bacteria with cholesterol-lowering activity from digestive tracts of Indonesian native chickens. Media Peternakan 40 (1): 35-41. DOI: 10.5398/medpet.2017.40.1.35

Kabir SML. 2009. The role of probiotics in the poultry industry. Int J Mol Sci 10: 3531-3546.

Kirbiš A. 2007. Microbiological screening method for detection of aminoglycosides, $\beta$-lactames, macrolides, tetracyclines and quinolones in meat samples. Slovenian Veterinary Research 44 (1/2): 11-18.

Kleerebezem M, Boekhorst J, van Kranenburg R, Molenaar D, Kuipers OP, Leer R, Tarchini R, Peters SA, Sandbrink HM, Fiers MWEJ, Stiekema W, Klein Lankhorst RM, Bron PA, Hoffer SM. Groot MNN, Kerkhoven R, de Vries M, Ursing B, de Vos WM, Siezen RJ. 2003. Complete genome sequence of Lactobacillus plantarum WCFS1. Proceedings of the National Academy of Sciences of the United States of America 100 (4): 1990-1995.

Lee K, Lee Y. 2009. Production of $\mathrm{c} 9, \mathrm{t} 11$ - and $\mathrm{t} 10$, c12-conjugated linoleic acids in human by Lactobacillus rhamnosus PL60. J Microbiol Biotechnol 19 (12): 1617-1619. DOI: 10.4014/jmb.0907.07010.

Linares DM, Gómez C, Renes E, Fresno JM, Tornadijo ME, Ross RP, Stanton C. 2017. Lactic acid bacteria and bifidobacteria with potential to design natural biofunctional health-promoting dairy foods. Front Microbiol 8: 846. DOI: 10.3389/fmicb.2017.00846.

Maldonado A, Ruiz-Barba JL, Jiménez-Díaz R. 2003. Purification and genetic characterization of plantaricin NC8, a novel cocultureinducible two-peptide bacteriocin from Lactobacillus plantarum NC8. Appl Environ Microbiol 69 (1): 383-389. DOI: 10.1128/aem.69.1.383-389.2003.

Masood MI, Qadir MI, Shirazi JH, Khan IU. 2011. Beneficial effects of lactic acid bacteria on human beings. Critical Rev Microbiol 37 (1): 91-98. DOI: 10.3109/1040841X.2010.536522.

Menconi A, Kallapura G, Latorre JD, Morgan MJ, Pumford NR, Hargis BM, Tellez G. 2014. Identification and characterization of lactic acid bacteria in a commercial probiotic culture. Biosci Microbiota Food Health 33 (1): 25-30. DOI: 10.12938/bmfh.33.25.

Menteri Pertanian Republik Indonesia. 2017. Peraturan Menteri Pertanian Republik Indonesia nomor 14/PERMENTAN/PK.350/5/2017 tentang Klasifikasi obat Hewan: 1-25. [Indonesian]

Perrière G, Gouy M. 1996. WWW-Query: An on-line retrieval system for biological sequence banks. Biochimie 78: 364-369.

Remiger A, Ehrmann MA, Vogel RF. 1996. Identification of bacteriocinencoding genes in lactobacilli by polymerase chain reaction (PCR). Syst Appl Microbiol 19: 28-34. DOI: 10.1016/S0723-2020(96)800051.

Settanni L, Corsetti A. 2007. Application of bacteriocins in vegetable food biopreservation. Int J Food Microbiol 121 (2): 123-138. DOI: 10.1016/j.ijfoodmicro.2007.09.001.

Tanous C, Chambellon E, Sepulchre AM, Yvon M. The gene encoding the glutamate dehydrogenase in Lactococcus lactis is part of a remnant Tn3 transposon carried by large plasmid. J Bacteriol 187 (14): 50195022. DOI: 10.1128/JB.187.14.5019-5022.2005

Todorov SD. 2009. Bacteriocins from Lactobacillus plantarum production, genetic organization and mode of action. Braz J Microbiol $40 \quad$ (2): 209-221. DOI: 10.1590/S151783822009000200001

Valero-Cases E, Frutos MJ. 2017. Effect of inulin on the viability of L. plantarum during storage and in vitro digestion and on composition parameters of vegetable fermented juices. Plant Foods Hum Nutr 72: 161-167. DOI: 10.1007/s11130-017-0601-x

Yunes RA, Poluektova EU, Dyachkova MS, Klimina KM, Kovtun AS, Averina OV, Orlova VS, Danilenko VN. GABA production and structure of gadB/gadC genes in Lactobacillus and Bifidobacterium strains from human microbiota. Anaerobe 42: 197-204. DOI: 10.1016/j.anaerobe.2016.10.011.

Zareian M, Ebrahimpour A, Mohamed AKS, Saari N. 2013. Modeling of glutamic acid production by Lactobacillus plantarum MNZ. Electronic J Biotechnol 16 (4): 1-17. 
Zhang R, Yang T, Rao Z, Sun H, Xu M, Zhang X, Xu Z, Yang S. 2014. Efficient one-step preparation of $\gamma$-aminobutyric acid from glucose without an exogenous cofactor by designated Corynebacterium glutamicum. Green Chem 16: 4190-4197. 